\title{
A Doctoral Seminar in Qualitative Research Methods: Lessons Learned
}

\author{
Suzanne Franco \\ Wright State University, Dayton, OH, USA
}

\author{
suzanne.franco@wright.edu
}

\begin{abstract}
New qualitative research methods continue to emerge in response to factors such as renewed interest in mixed methods, better understanding of the importance of a researcher's philosophical stance, as well as the increased use of technology in data collection and analysis, to name a few. As a result, those facilitating research methods courses must revisit content and instructional strategies in order to prepare well-informed researchers. Approaches range from paradigm to pragmatic emphasis. This descriptive case study of a doctoral seminar for novice qualitative researchers describes the intricacies of the syllabus of a pragmatic approach in a constructivist/social constructionist learning environment. The purpose was to document the delivery and faculty/student interactions and reactions. Noteworthy were the contradictions and frustrations in the delivery as well as in student experiences. In the end, student input led to seminal learning experiences. The confirmation of the effectiveness of a constructivist/social constructivist learning environment is applicable to higher education pedagogy in general.
\end{abstract}

Keywords: qualitative research methods, pragmatism, researcher worldviews, conceptual frameworks, research model

\section{Introduction}

As the first cohort of doctoral students in a new doctoral program began to consider research methodology for investigating their dissertation topics, it became apparent to many of the program advisors that the students needed supplementary training regarding the complexities and emerging methods of qualitative research. Because numerous student research topics were wellsuited for qualitative inquiry approaches, a three-hour one semester qualitative methods seminar was offered to fill the noted gap. The challenge was to develop a course that not only addressed the multitude of qualitative methods available but also helped each student frame their expanded knowledge for personal research interests. This paper presents a descriptive case study to identify practical consequences and lessons learned through the development and delivery of a qualitative research methods seminar that used a "big tent" design in a constructivist/social constructivist

(CC BY-NC 4.0) This article is licensed to you under a Creative Commons Attribution-

NonCommercial 4.0 International License. When you copy and redistribute this paper in full or in part, you need to provide proper attribution to it to ensure that others can later locate this work (and to ensure that others do not accuse you of plagiarism). You may (and we encourage you to) adapt, remix, transform, and build upon the material for any non-commercial purposes. This license does not permit you to use this material for commercial purposes. environment to introduce multiple qualitative methods and applications with assignments to help personalize the new knowledge. The findings add to the body of knowledge to address effective teaching of qualitative research methods to graduate students. Noteworthy are the contradictions to my expectations, the problems that arose during the delivery, and the insights that emerged.

Editor: David H. Kahl Jr.

Submitted: June 26, 2016; Revised: September 10, September 18, 2016; Accepted: September 19, 2016 


\section{Literature Review}

Since the late 1960s new qualitative methods and analysis techniques have continued to emerge. For example, Glaser and Strauss documented grounded theory and the constant comparative method of coding qualitative data in 1967. More recently, Sawyer and Norris (2012) presented duo-ethnography to the qualitative research field as a new dialogical method for understanding complex phenomena and topics of interest from multiple perspectives. It is as if qualitative researchers are no longer deterred by the predominance of positivist quantitative research methods but instead are exploring unique, diverse methods for collecting and interpreting qualitative human and social data in the current culture (Gelo, 2012). The proliferation is a natural step in Kuhn's (1962) description of a paradigm shift in normal science. During a shift in what is considered normal science, multiple alternatives are introduced to the scientific community. Alternatives are either rejected or accepted over time. In this case the shift is from quantitative methods (normal science) being the one gold standard for research design to quantitative, qualitative, and mixed methods being gold standards in the realm of normal science of research (Kosinets, 2012; Mcvilly, Stancliffe, Parmenter, \& Burton-Smith, 2008; Ponterotto, 2005).

Within the field of qualitative research, there is no dominant approach. The field can be appropriately described as polyphonic with multiple thriving symbiotic and individual interest groups. For example, the relatively new method, duo-ethnography, is extremely personal and introspective wherein researchers re-conceptualize their philosophical stance within the research (Sawyer \& Norris, 2012). The method accentuates a renewed focus on the link between researcher philosophical stance and research by emphasizing conversations rather than tests; researcher empathy is encouraged and welcomed since the researchers themselves are considered the site for the research. In addition, netnography is a form of ethnography that uses data from online communities as the primary data source. When the data are gathered from sometimes unmoderated online discussions, there is no moderator who might shape the data collection through follow-up questions (Hollyoak, 2014). The development of these and other emerging research methods demonstrates that many research communities are including qualitative and mixed methods in the normal science of research, though not all.

As qualitative approaches multiply, those charged with teaching graduate level research methods courses have had to re-think how to prepare students as qualitative, quantitative, and mixed methods researchers (Hesse-Biber, 2015; Onwuegbuzie \& Leech, 2005). Breuer and Schreier (2007) posited that approaches to teaching qualitative research falls along a continuum from paradigmatic to a pragmatic. The paradigmatic approach introduces students to the conventional qualitative paradigms (case study, ethnography, phenomenology, narrative inquiry, and grounded theory) and data collection skills (interviews, surveys, and observations). Students implement each paradigm by a set of rules and guidelines. Drisko (2016) reported that, unfortunately, students in such courses demonstrate obvious misunderstandings regarding knowledge and terminology.

On the other end of the continuum, a pragmatic approach presents the field of qualitative research as continuously expanding to reflect cultural shifts. Researchers instructed with a pragmatist approach should be able to design quantitative, qualitative, or mixed methods research projects that are appropriate for the research topics (Onwuegbuzie \& Leech, 2005). The term 'pragmatist researcher' does not refer to the epistemological view of pragmatism; there is no one-to-one relationship between method and epistemology. Instead, a pragmatist researcher is one who is aware of numerous available research techniques and who "select[s] methods with respect to their value for addressing the underlying research questions, rather than with regard to some preconceived biases about which paradigm [qualitative or quantitative] is a hegemony in social science research" (Onwuegbuzie \& Leech, 2005, p. 291). The pragmatist approach emphasizes the importance of researcher philosophical stance and the relationship between philosophy and research. 
Throughout the continuum of approaches to teach qualitative methods at the graduate level, roadblocks emerge for students and educators. For example, it is still common for students and administrators to reject the need for teaching qualitative research, and/or to acknowledge the need to update how qualitative research methods courses should be presented (Eaking \& Mykhalovskiy, 2003). In addition, many graduate qualitative methods faculty were trained as quantitative researchers in a positivist world using the scientific method to determine truth (Creswell, Tashakkori, Jensen, \& Shapley, 2003; Earley, 2014; Hesse-Biber, 2015; Keen, 1996; Stallings, 1995).

Creswell et al. (2003, p. 620) referred to these faculty as "the first generation of faculty" who are learning and teaching some portions of research methods simultaneously.

Furthermore, a qualitative methods graduate student is often surprised at the amount of work and concentration required to become a qualitative researcher (Webb \& Glesne, 1992). Such students are frequently well trained in quantitative methods but not prepared for psychological challenges as they grapple with identifying their philosophical stance. Unless students have past experiences in philosophy or psychology, they find it difficult to distance themselves from the positivist paradigm and embrace a philosophical stance that truly represents their worldview or how they see life without confusion and resistance (Drisko, 2016; Schnelker, 2006). In fact, Carawan, Knight, Wittman, Pokorny, and Velde (2011) discovered that their students had considerable difficulty in shifting out of a positivist worldview and embracing the link between philosophy and research.

\section{Goal and Syllabus of Seminar on Qualitative Methods}

As Drisko (2016) noted, qualitative research methods educators must strategize how to teach students the knowledge, values, skill, self-awareness, and reflexivity to become effective qualitative researchers. The overall goal for the qualitative methods seminar in this study was to provide a pragmatist exposure to (a) the complexities of qualitative research including multiple emerging methods, and (b) the importance of a conceptual/theoretical framework in a qualitative inquiry. In this study, the term complexities includes the importance for a researcher to reflect on his or her personal philosophical stance, to understand how a researcher's epistemology and ontology impacts him or her as a research instrument, and to develop awareness of the proliferation of qualitative research methods, My constructivism/social constructivist beliefs that students create their own knowledge through inquiry as well as through collaboration with peers (Dewey, 1916; Vygotsky, 1962) along with the published literature about approaches to teach qualitative research (Drisko, 2008; Onwuegbuzie \& Leech, 2005) guided the development of the syllabus.

Two text books were selected: Jones, Torres, and Arminio's (2014) Negotiating the Complexities of Qualitative Research in Higher Education: Fundamental Elements and Issues and Anfara and Mertz's (Eds.) (2015) Theoretical Frameworks in Qualitative Research. In preparation for the seminar, I had multiple communications with the text book authors and editors, as well as chapter authors. The Jones et al. (2014) text included a great deal of dialogue regarding researcher epistemology, ontology, and researcher's worldview connections to research. The Anfara and Mertz (2015) text provided examples of theoretical frameworks used in research in multiple disciplines.

At the same time, to address the need for exposure to the numerous existing and emerging qualitative methods, I conducted an extensive literature review to locate exemplar empirical research articles that documented applications of classical and evolving qualitative paradigms. Topics addressed and demonstrated in those articles included narrative methods, phenomenology, autoethnography, duo-ethnography, grounded theory, case study, meta-analysis of qualitative studies, trustworthiness, appreciative inquiry, empowerment evaluation, code book development, transcendental methodology, queer theory, and numerous views of the qualitative/quantitative dilemma. 
The weekly activities included discussions of the textbook readings and student-led reviews of assigned articles. The "big tent" teaching and learning philosophy set the framework, illuminating that there is not one dominate model or qualitative method but numerous methods and models for all disciplines (Huber \& Hutchings, 2005, p. 30); my belief that deep learning occurs when students reflect and co-construct knowledge with peers influenced the design. In addition to the weekly readings, discussions and class presentations, there were five assignments designed to personalize the learning according to each students' research interests and potential use of qualitative methods. The assignments listed below include details for the students plus the related rationale for how the assignment would contribute to students' growth as qualitative researchers.

Assignment 1. Focus of your research: Provide a 1 - 2 page description of your research problem, purpose statement, research question(s), data collection methods and procedures, including the research design.

In exploring new or confusing concepts throughout the course, students used their individual research interests and experiences to frame questions and concepts. Assignment 1 created the foundation for future discussions regarding progress towards growth as qualitative researchers.

Assignment 2. Self-reflection on learning: Maintain a reflection journal about your learning and growth regarding qualitative methods. At the end of the semester submit a final 5-8 page integrated reflection paper about individual learning. The reflection journal maintained throughout the semester will be the primary source for this assignment.

The reflection journal also provided opportunities for students to describe the journey of becoming qualitative researchers. Students could document their journey through studying and identifying philosophical stance, discuss new methods that they might use in their dissertation, and comment on the variety of conceptual/theoretical frameworks available. The reflection journal and final paper were means for students to construct their new knowledge over time.

Assignment 3. Presentation regarding methodology or method: Students will select one article related to the method described in Assignment 1 (e.g. Ethnography, Grounded Theory, Narrative Inquiry, Case Study, Phenomenology, etc.) or the data collection plan (e.g. Interviews, Focus Groups, Qualitative Software, Photo voice, etc.) and present a critique of the article to the class.

In preparation for the presentation, students immersed themselves into literature related to a topic of interest. Students identified the sections of the article that included positionality, conceptual/theoretical framework, theory, methods, and analysis. Aggregating the information into a presentation for classmates forced students to synthesize the information in a succinct manner for the presentation as well as to provide additional details when needed. Assignment 3 provided the opportunity for students to construct new knowledge through the experience of creating the presentation. Delivering the presentation allowed for learning with peers.

Assignment 4: Peer review and final summary of student research: Students will present their individual research project for discussion and feedback at least once during the semester. Peers will provide written and oral feedback. At the end of the semester, students will submit a final individual research plan including all sections of a typical methods chapter in a thesis or dissertation. Details that should be included are self-reflection summary regarding the student as a researcher, statement of research problem/topic, subjectivity/positionality statement, conceptual/theoretical framework of research, data collection method(s), sampling/interview protocol, ethical considerations, trustworthiness/rigor, and data analysis or summary, to name a few.

The final version of the students' research plans required the students to consider the emerging qualitative methods as options, to connect their philosophical stance to their research design, to describe how their philosophical stance impacted the research design and analysis, and to adopt a 
conceptual/theoretical framework. Like Assignments 2, 3 and 4, the activity reflected growth related to becoming qualitative researcher.

Assignment 5: Qualitative Meta-synthesis: Students will conduct a mini qualitative metasynthesis using three or four articles about qualitative research related to their research topic (subject, methods or both). Students will find the articles, compare and classify findings across the three or four articles, and use meta-synthesis techniques to integrate the qualitative research findings. Each student will discuss and present the meta-synthesis to the class during the final class.

The meta-synthesis was designed to deepen student experiences regarding becoming a qualitative researcher. A meta-synthesis forces students to experience the challenges in finding and using multiple study findings to suggest a new interpretation of findings. In doing so, the new knowledge gained from the class activities supports their ability to acknowledge the variety of author philosophical stances, conceptual/theoretical frameworks and methods used. Selfawareness of their own philosophical stance is required to complete the assignment.

Though students' personal interests served as the foundation for the assignments, the course design and assignments included multiple readings and class discussions regarding multiple approaches to implementing qualitative research. Those who complete the course will be trained to be pragmatic qualitative researchers.

\section{Methods}

The method selected for this study was a case study. Flyvbjerg (2001) identified four criteria for selecting a case study method: extreme/deviant case, maximum variation cases, critical case, and paradigmatic case. Because the inaugural delivery can only be studied during the delivery, the study of the course delivery was considered to be an extreme case and thus appropriate for a case study approach. The case study is a descriptive case study because, according to Yin (2009), a descriptive case study is one that completely describes different characteristics of a phenomenon in its context. For this case study, the phenomenon was the inaugural delivery of the three semester hour graduate level qualitative methods seminar to novice qualitative researchers.

The research question for this descriptive case study was the following: How does a qualitative methods seminar for doctoral graduate students contribute to students' understanding of the (a) complexities of qualitative research and the (b) importance of conceptual/theoretical framework in qualitative research? Complexities of qualitative research included philosophical stance, a link between philosophy and research, and proliferation of qualitative methods. To understand the intricacies within the development, delivery, and student responses, the bounded unit for the case, or the unit of study, was the classroom. Four propositions emerged based on findings of Carawan et al. (2011), Drisko (2008, 2016), Schnelker (2006) and Staller (2013). Propositions were that the novice qualitative researchers were (a) unaware of the link between researchers' philosophical stance and their research, (b) unaware of their own epistemology and ontology, (c) unfamiliar with the importance of a conceptual/theoretical framework within a research design, and (d) unfamiliar with the ongoing proliferation of qualitative methods. Pragmatism was the qualitative inquiry framework employed in the quest to identify practical consequences and useful insights.

\section{Participants}

The four students who elected to enroll in the seminar were from two colleges within a mid-size public university in the Midwest region of the United States: The College of Education and Human Services (CEHS) and the College of Mathematics and Science (CoSM). Three students were members of the first cohort of a new doctoral program in CEHS; all held full time employment. The fourth member was a full-time doctoral student in CoSM working as a graduate research as- 
sistant in a longitudinal qualitative study. All four represented the population. The limitation that the sample size had on the findings is addressed in the Limitations section.

\section{Data Collection}

The University Research and Sponsored program determined that the study is not considered human subject research and therefore did not require IRB approval. According to assignment due dates, students submitted the assigned work into an instructional management system (IMS). My follow-up responses to student submissions were posted in the IMS. Additional conversations frequently took place during class time. I maintained a reflection journal during the three semester hour graduate level seminar.

\section{Context}

The three doctoral students from the CEHS doctoral program had completed two semesters of research methods coursework: (a) one semester that included data analysis skill development for quantitative research, as well as an introduction to coding/ theme development, observations, interviews and focus groups for qualitative research, and (b) one semester that focused on research question development, model building and quantitative methods. The CoSM student had not completed a research methods courses in her doctoral program but had completed quantitative analyses coursework in her graduate program.

\section{Positionality}

I have extensive experience in qualitative, quantitative, and mixed methods research through serving as Principal Investigator and Evaluator in numerous funded empirical studies, serving as dissertation/thesis chairs and committee members for quantitative and qualitative research, and delivering quantitative and qualitative research methods courses at the graduate level for over ten years. As a public school and higher education teacher for almost 30 years, I am a constructionist/social constructionist who believes that multiple realities are constructed by different groups of people: there is no one truth. Moreover, I believe that people construct new knowledge by experience and collaboratively with peers. Serving as a frequent evaluator, my interpretations and research analyses are also influenced by pragmatism. In my leadership roles as well as in the classroom, I am a humanist in that I strive to respect the dignity of each life and treat family, students and colleagues with ethics, compassion, and responsibility (Hancock, 2011).

\section{Instruments}

The student weekly reflections, student papers, and final course evaluations were the instruments used to glean a thick description of the delivered course from the students' perspective. Student reflections were responses to open ended questions based on readings/topics assigned; formal papers were required to accompany student class presentations and for self-directed research planning based on individual topics of interest. Final course evaluation questions were aligned with the course objectives. An additional data source from an instructor's perspective was my reflection journal.

\section{Analysis}

Document analysis (Bowen, 2009; Corbin \& Strauss, 2008) as a qualitative method within the descriptive case study was utilized as I identified factors influencing students' understandings of qualitative methods. The analysis strategy included a second review of all student artifacts along with relevant reflective journal entries after the completion of the course. This step allowed me to reflect holistically on the entire course rather than rely on memories. During the reflection over 
the semester course, themes emerged from all artifacts and assignments: worldview, paradigms, theory, common language, conceptual/theoretical framework, frustrations, personal conundrums, the qualitative/quantitative argument, and lessons learned. Complete sentences from the artifacts were coded to appropriate themes in order to retain context of the sentences. As a result, a sentence could be coded to multiple themes. I coded the data from student artifacts and my reflection journal.

The research question is, How does a qualitative methods seminar for doctoral graduate students contribute to students' understanding of the (a) complexities of qualitative research and the (b) importance of conceptual/theoretical framework in qualitative research?

The findings are organized by the four propositions defined for the case study:

Proposition A: Students were unaware of their own epistemology and ontology.

Students documented that they had not considered their views of reality, of being, or of how knowledge is formed.

"These words [epistemology and ontology] are new to me and hard for me to understand."

"I am seeing more and more references to the importance of worldview of researchers. How could I have missed this?"

Students declared that they were positivists after the initial activity regarding philosophical stance. In addition, students were reluctant to share their views and uncomfortable when others' views were different from their own.

"I am afraid that my explanations about my beliefs may offend my classmates. I find it difficult to talk about my beliefs because I have to be so careful with the words I use.

Analyses confirmed Staller's (2013) finding that abandoning the positivist theory was difficult. One student stated that she feared she was abandoning her family upbringing if she did not embrace there being one truth, positivism.

\section{"I know I am a positivist because my parents are."}

In the end, the qualitative methods seminar for doctoral graduate students introduced the philosophical underpinnings for epistemology and ontology and provided opportunities for students to explore their personal philosophical stance. The activities and artifacts indicated that students eventually determined that they were not positivists. In fact, one student embraced post positivism, two embraced interpretivism, and one embraced critical theory.

Proposition B: Students were unaware of the link between researchers' philosophical stance and their research.

In the qualitative methods seminar for doctoral graduate students, the concept of paradigms continued to plague students' ability to absorb qualitative methods text references and articles. Within paradigms, the theme of "common language" was noted as a barrier to embracing philosophy as part of research.

"Why can't these authors agree on terminology?"

"I feel like I should make up my own terms...I would understand them then."

"I cannot believe that my worldview, or whatever you want to call it, impacts my research design or analysis." 
"If worldview is so important to qualitative research, then why am I just now hearing about this? The Jones text is the first time I have seen this and I am unsure if it is just one person's belief or a standard."

"I find the Jones text poorly written and very confusing."

"I am unsure why the students have such an aversion to the information in Jones' textbook. I find it so helpful.' (me)

The reluctance to embrace the relationship between philosophy and research reflected Schnelker's (2006) findings and appeared to be related to the novelty of realizing that each student had different worldviews. During the planned course activities, students did not wholly embrace the existence of the link between researchers' philosophical stance and their research. In fact, the revised final project provided the first evidence that the students accepted that there is a link; there never was a class discussion regarding the fact that such a link does exist. One student did acknowledge the existence of the link in a final reflection quote: "the link between research and positionality is not debatable."

Proposition C: Students were unaware of the importance of theoretical/conceptual framework in qualitative research.

Within the artifacts from the qualitative methods seminar for doctoral graduate students there were reports that students liked seeing examples of conceptual/theoretical frameworks used by senior researchers and by doctoral students in the Anfara and Mertz (2015) text. The purpose for using a conceptual/theoretical framework was understood and accepted. Drisko (2016) emphasized the importance of a conceptual/theoretical framework as do other authors regarding teaching qualitative research methods.

"The examples about using conceptual frameworks in research made it easy for me to accept their importance."

"I liked the short summaries written by doctoral students, especially since the summaries included frameworks considered and rejected."

Proposition D: Students were unfamiliar with the ongoing proliferation of qualitative methods.

Students in the qualitative methods seminar for doctoral graduate students reported that they were more aware of the historical schism between qualitative and quantitative research than they were aware of the ongoing proliferation of qualitative research methods. Many of the assigned articles describing new methods provided the historical perspective of the evolution of the method, which interested them. There were no entries regarding the proliferation of methods or the increased acceptance of qualitative methods. Perhaps the students viewed the increased credibility of qualitative methods and the proliferation of methods as old news.

"Not sure why quantitative methods dominated for so long. Short sighted to me."

Regarding the research question for this study, examples of practical consequences and useful insights regarding how the course contributed to their understandings of the complexities of qualitative research and regarding the importance of conceptual/theoretical framework in qualitative research are below.

"Qualitative research is much more complex that I had imagined before taking this class."

"The examples about using conceptual frameworks in research made it easy for me to accept their importance." 
'Dr. Follett (the guest speaker) provided an engaging longitudinal perspective for novice graduate research students who are learning about the complexities of qualitative research. She added credibility to the importance of researchers' awareness of their own philosophical stance and how there is a link between philosophy and research." (me)

\section{Limitations}

A significant limitation to this study was the sample size of four. There are a number of reasons for the small number. For one, the doctoral program is small and new. Secondly, the faculty did not recognize the students' lack of depth in qualitative methods until the students began to prepare for their dissertation research. As a result, the class was developed rather quickly.

Regardless of the reasons the sample was small, the impact of such a small sample in any study is in the findings. In a class of size four, one student can influence the other three either by dominating or by having minimal input. In addition, students can be reluctant to disagree with others for fear of being ostracized for being different. The case study is not designed to be generalizable but can contribute to theory building (Yin, 2009). In this case study, the four students worked well as a group of four; the reflections and journals did not indicate that there were problems getting along with any of the others. In fact, the model building experience reflected four students who were able to collaborate and develop together effectively.

Future research regarding a doctoral qualitative methods seminar should consider alternative research design if enrollment is low.

\section{Trustworthiness}

Trustworthiness as it relates to qualitative research reflects credibility, dependability, confirmability, and transferability (Shenton, 2004). Credibility was increased through the use of multiple sources of data including all student submissions and my reflection journal. To further increase credibility, students provided feedback on the drafts of this paper. Their suggested improvements were implemented.

Both dependability and confirmability can be tested through investigator triangulation which requires the researcher to share observations with other researchers (Denzin, 1994). Dependability and confirmability were increased when I shared and confirmed my observations and analyses with colleagues in my department. Transferability is not the target for a descriptive case study. However, researchers can increase transferability in case studies by including rich levels of descriptors that provide the reader with full awareness of the inner workings of the bonded limits of the case study (Stake, 2005). The level of detail provided in this case study increased this study's transferability.

\section{The Seminar Delivered}

\section{Introducing Theoretical Perspective}

To assist students in understanding how research questions are located in a theoretical tradition, a first- week activity was assigned to help students explore their personal worldview or philosophy of life. Students were directed to review each line in Appendix A and to circle the statement in each line that most accurately/closely represented their views of knowledge and reality. Each column represented differing worldviews: positivism/post positivism, behaviorism, critical theory, and postmodernism. All students identified themselves as positivists.

Probing questions about the meaning of truth and reality provided an opportunity for the students to reconsider their original stance. Students participated awkwardly with halting phrases and they 
struggled with terminology; there were frequent conflicting understandings of the worldviews represented in the continuum. Students were uneasy with the fact that others did not see the world as they did. There was a level of frustration and uneasiness as students wrestled with abandoning their former comfort zones such as positivism; they also struggled with processing the differing opinions among fellow students. Staller's (2013) findings regarding students struggling with these concepts were unfolding before my eyes.

Adding to the students' conundrums was the use of multiple terms for what were seemingly the same concepts. Students consulted different texts for clarifications and discovered alternative terminologies to describe the same concepts (paradigms/methods, objectivism/positivism; constructivism/constructionism, worldview/philosophical stance, empiricism, etc.) The plurality along with their unfamiliarity with philosophy contributed to their unwillingness to embrace the importance of the researcher's philosophical stance. Their opposition was reminiscent of the skeptics in Kuhn's (1962) descriptions of revolutions in scientific discipline throughout history. Like the skeptics, the students renounced the premise of the importance of the researcher's philosophical stance because they did not understand the profound link between philosophy and research.

In retrospect, the students were experiencing a type of cognitive overload because merely learning about the importance of theoretical perspectives did not convince them of the importance of their personal perspective with regard to research. First they had to identify and embrace their own philosophical stance. Moreover, the opinions and models intersected, conflicted, and interfered with others. Their former learning experiences had trained them to employ logic in their pursuit of knowledge, but they saw no logic for identifying their philosophical stance in their pursuit of research (Schnelker, 2006). In the initial Appendix A exercise, some responses fell across more than one philosophical stance and yet there was no explanation in the Jones et al. (2014) text about how this could happen or what it would mean. Having only been exposed to the positivist stance wherein there is one truth, students were uncomfortable and unsure of what it meant about them as researchers to agree with statements associated with more than one stance, especially one other than positivism. They viewed the activity and subsequent discussions as frustrating and not helpful.

Each week, students participated in the discussions and submitted reflections associated with the Jones et al. (2014) textbook. Discussions about the differing philosophical stances and/or the importance of philosophical stance in research frequently reflected their skepticism about the importance of philosophy; the rejected premise was like the elephant in the room that students wanted to avoid. Some authors of additional reading assignments confirmed the importance; others did not. In the assigned readings, some authors included information about their philosophical stance in their writings, thus making the link to research design apparent; others did not. Students began to complain about the text and students began to disengage. After seven weeks of the semester, the students' general position was that a researcher's stance may develop over time (as theirs had throughout the seven weeks) and that a researcher's philosophical stance may be different depending on a particular research topic. The position was a type of compromise, reflecting progress towards acknowledging that individuals do have a philosophical stance and that there may be a link between philosophy and research. I questioned the effectiveness of my instructional strategies and watched the elephant in the room grow larger.

\section{Introducing Conceptual/Theoretical Frameworks}

The second week of the course included discussion around the importance of conceptual/theoretical frameworks for qualitative research. Fowler's (2015) chapter in the Anfara and Mertz (2015) text included detailed descriptions of Fowler's experiences regarding conceptual/theoretical frameworks in both her graduate level research and doctoral dissertation. The author 
described how she learned about Mazzoni's (1991) arena model for policy innovation and why, as an academician, she subsequently adopted the framework for future research projects. Also included in the assigned chapter were the alternative conceptual/theoretical frameworks she considered along with her logic for not selecting the alternative frameworks.

The students' reflections and discussions about the chapter readings were positive, lively, and almost celebratory because students indicated they 'got it' (unlike the philosophical stance discussion the previous week!). The Fowler (2015) chapter provided details that further illuminated the importance for a conceptual/theoretical framework. During the discussion, one student commented that 'Every doctoral student should take this course or read this chapter.' Another student lamented that she would like to ask the author a few more questions; others agreed. Surprisingly quick research revealed that the author lived relatively close to the campus. When contacted, Fowler agreed to be a guest speaker for the seminar. Prior to her visit, the students compiled and sent a list of questions to her. More details about her visit follow this section.

In preparation for the Anfara and Mertz (2015) discussions, the students contacted their assigned chapter's author by email or phone for additional information. In the final course reflections, the students noted that personal communication with the chapter author was illuminating and provided context for the author's research topic and philosophical stance. The chapter authors usually referenced at least one of their published articles as an example of the use of a conceptual/theoretical framework described. Students reported that reading the specific article referenced in the Anfara and Mertz (2015) chapter provided deeper understanding and consequently enhanced their learning. They were constructing their knowledge from exchanges with researchers in the field and sharing their new knowledge with their classmates. In essence, they were personalizing their learning through the communication with the authors, a form of Vgotsky's social constructionism (1962).

'I was able to comprehend the rationale behind her decision to select...the theoretical framework.'

'I could comprehend how the theoretical framework then informed...the research questions, methodology, and methods.'

\section{Guest Speaker}

Fowler was a guest speaker during the ninth week of the twelve-week semester. Students and faculty throughout the college were invited to attend; there were approximately 25 attendees. The topics she discussed fell into three themes: (a) advice for doctoral students, (b) specifics about the conceptual/theoretical framework (Mazzoni, 1991) described in the Anfara and Mertz (2015) chapter and the influence of her work on said framework, and (c) clarification about her philosophical stance, its importance, and whether it had evolved or remained constant through her career.

Fowler addressed the realities of the professoriate in her rationale for choosing her framework and topics of research. She elaborated that faculty must be cognizant of the link between becoming tenured and maintaining a research agenda. She also described her impact on Mazzoni's arena model of policy innovation (1991) as being minimal, sharing that only at the end of her academic career did she realize that she could have collaborated with Mazzoni to further discuss and modify the arena model. In addition, she acknowledged the loneliness of the dissertation journey and advised students to keep the focus on the end of the journey and to seek advice and help when needed.

Interestingly, when students sent topics for discussion to Fowler, each student had included a question inquiring about her view of the importance and/or link between philosophical stances 
and research. As described earlier, the importance of a researcher's philosophical stance continued to be a conundrum for the students even at this late date.

Fowler addressed the student questions about philosophical stance at the end of her visit. First she articulated why a researcher's philosophical stance impacts both qualitative and quantitative research and methods, providing personal details and connecting the details with research methods. She described her personal worldview and provided details about how her worldview had developed over time and impacted her work; moreover, she emphasized that each person's life experiences influence the development of a worldview/philosophical stance. And finally, she explained that in her opinion, the reticence of the current generation to discuss spirituality as it relates to research and the researcher makes it hard for new researchers to understand the link between philosophical stance and research. The audience responded to this section of the lecture with requests for more details about her journey as an academic researcher. The students' verbal and nonverbal responses indicated they were deeply engaged with the guest speaker's statements regarding philosophical stance and its link to research.

An hour of class time remained after Fowler's presentation. As my planned activity for the last hour of class began, students requested time instead to process all they had learned from Fowler rather than focus on the topic at hand. In the ensuing discussion they enthusiastically commented about what they heard and energetically compared their interpretations with other classmates. Their words and actions during this 'processing' reflected more comfort with the complexities of qualitative research than during any other time in the semester. The dialogue demonstrated a deep synthesis of the previous readings, article reviews, and guest speaker presentation. Interestingly, they listened to each other with greater openness. They were actively involved in co-construction of knowledge about qualitative research. Fowler's presentation from the perspective of an entire academic career served as a catalyst for their acceptance of the importance of philosophy with regard to research. Her personal experiences added the missing pieces to help them know AND understand the link. The elephant in the room was shrinking.

Verbally and nonverbally, the students emulated determination to solidify their new understandings of the link between philosophy and the research process. In the end, they proposed that they develop a visual model to reflect their new understandings and to contribute to future students' experiences regarding embracing this complex field of qualitative research. I reluctantly agreed to substitute the students' proposed development of a visual model of the research process for the meta-synthesis project (Assignment 5). I was hopeful the group effort and collaboration would provide a rich experience for continued co-construction of knowledge and would contribute to their growth in understanding the complexities of qualitative research more than completing the meta-synthesis assignment. In addition, I was hoping the elephant in the room was continuing to reduce in size.

\section{Redefined Final Project}

The remainder of the classes for the semester consisted of group work for the redefined final project regarding developing the model for research. Everyone actively participated. The students enumerated items to include in a model of the research process; they aggregated the items within themes in an iterative fashion. Unlike the earlier classes during which frustration and skepticism dominated conversations regarding the link between philosophy and research, the class energetically came to some middle ground. Their actions and words reflected a new understanding of the research process and the realization that each person has a philosophical stance that is a unique, important link to his or her research. They grappled with alternatives for portraying the research process concisely and visually, given this newly embraced link. Observing but not contributing to the process, I was assured that their activities were contributing to their understandings about qualitative research and philosophy. The elephant was hard to find. 
A variety of formats were considered; a tree was selected as the most appropriate for their conceptualization of the research process. Appendix B depicts the final model. The collaboratively developed title, The research process: The seen and the unseen, embodies the students' understanding of the connection between the research process and the researcher's worldview, lived experiences, ontology, and epistemology. The model is framed as an expansive tree; its deep root system below ground level is included in the model. The significant root system represents the unseen and sometimes stealth systems that contribute to research, such as the researcher's lived experiences, epistemology, ontology, and spirituality. The students named this confluence of unseen systems (the tree trunk emerging from the ground) as a researcher's positionality. In their model, the tree roots and resultant emergent trunk, or researcher's positionality, rises up, providing the solid foundation for the commonly documented, universally recognized or classic 'seen' portions of a research project such as the research question, methodology, findings, ethics and recommendations.

\section{Summary}

The seminar was developed and delivered to contribute to students' growth as qualitative researchers. The case study research question centered on how the qualitative methods seminar for doctoral graduate students contributed to their growth. The students' artifacts reflected that the limiting factor for the novice qualitative researchers emerged from their being novice researchers, unaware of their own philosophical stance, the range of philosophies and worldviews, and the link between philosophy and research. In the artifacts, students reflected on and constructively identified their personal philosophical stances, noted that a researcher's worldview impacts him or her as a research instrument, accepted the need for a conceptual/theoretical framework for research design and analysis, and described qualitative research methods that documented their awareness of the proliferation of qualitative research methods,

Fowler's presentation served as an unintended catalyst for the confluence of student learning in the latter part of the semester. In the end, the students' extensive reading, confounding self-study, and open discourse led to a powerful co-construction of knowledge in the form of a model for research. The model effectively depicts the students' understanding that researchers who acknowledge that the research process consists of seen and unseen aspects are better prepared to design and implement quality research in our current culture... because as one student summarized, the "link between research and positionality is not debatable."

As the instructor, I, too, gained an unexpected insight regarding the importance of student voices. In fact, student voices brought about two seminal changes in the curriculum as presented. For example, the invitation to Fowler to visit the class originated from the students' request; Fowler's topics for discussion originated from the students' suggested topics; and the development of a research model came forth as a result of students' pleading requests to allow them to capture their new understandings about research as a collaboratively developed model for research. In other words, students articulated methods they deemed most helpful for their growth as researchers.

An important lesson learned for qualitative methods educators is that students will embrace the complexities of qualitative research once they invest in exploring their own philosophical stance and accept that one's experiences impact what and how he or she implements research. However, students will not necessarily embrace philosophy and accept the link between philosophy and research without debate.

This case study description includes examples of constructivist (Dewey, 1916) and social constructionist learning (Vygotsky, 1962). Students rejected the premise being presented, grappled with the inconsistencies within the literature, and suggested learning modes to help them expand their knowledge. The unsettling and sometimes contentious student interactions laid the founda- 
tion for meaningful co-construction of knowledge in the end. Regarding higher education instruction in general, the results confirm the validity of the social constructive and constructivist learning environment for graduate students who are developing knowledge and skills in their quest to contribute to society.

\section{References}

Anfara, V., \& Mertz, N. (Eds.). (2015). Theoretical frameworks in qualitative research (2nd ed.). Thousand Oaks, CA: Sage.

Bowen, G. (2009). Document analysis as a qualitative research method. Qualitative Research Journal, 9(2), $27-40$.

Breuer, F., \& Schreier, M. (2007). Issues in learning about and teaching qualitative research methods and methodology in the social sciences. Forum: Qualitative Social Research, 8(1), Art. 30. Retrieved September 9, 2016, from http://nbn-resolving.de/urn:nbn:de:0114-fqs0701307

Carawan, L., Knight, S., Wittman, P., Pokorny, M., \& Velde, B. (2011). On becoming a qualitative researcher: A view through the lens of transformative learning. Journal of Teaching in Social Work, 31(4), 387-399.

Corbin, J., \& Strauss, A. (2008). Basics of qualitative research: Techniques and procedures for developing grounded theory (3rd ed). Thousand Oaks, CA: Sage.

Creswell, J., Tashakkori, A., Jensen, K., \& Shapley, K. (2003). Teaching mixed methods research: Practices, dilemmas, and challenges. In A. Tashakkori \& C. Teddlie (Eds.), Handbook of mixed methods in social \& behavioral research (pp. 619-637). Thousand Oaks, CA: Sage.

Denzin, N. (1994). The art and politics of interpretation. In N. Denzin \& Y. Lincoln (Eds.), Handbook of qualitative research (pp. 500-515). Thousand Oaks, CA: Sage.

Dewey, J. (1916). Democracy and education: An introduction to the philosophy of education. New York: Macmillan.

Drisko, J. W. (2008). How is qualitative research taught at the master's level? Journal of Social Work Education. 48, 85-101.

Drisko, J. W. (2016). Introducing a special issue: Teaching qualitative research and inquiry. Qualitative Social Work 15(3), 303-306.

Eaking, M., \& Mykhalovskiy, E. (2003). Reframing the evaluation of qualitative health research: Reflections on a review of appraisal guidelines in the health sciences. Journal of Evaluation of Clinical Practice, 9(2), 187-194.

Earley, M. (2014). A synthesis of the literature on research methods education. Teaching in Higher Education, 19, 242-253.

Flyvbjerg, B. (2001). Making social science matter. University of Oxford.

Fowler, F. (2015). Struggling with theory: A beginning scholar's experience with Mazzoni's arena models. In V. Anfara \& N. Mertz (Eds.), Theoretical frameworks in qualitative research (2nd ed.) (pp. 42-61). Thousand Oaks, CA: Sage.

Gelo, O. (2012). On research methods and their philosophical assumptions: Raising the consciousness of researchers, again. Psychotherapie \& Sozialwissenschaft, 2(2012), 109-128.

Glaser, B., \& Strauss, A. (1967). The discovery of grounded theory: Strategies for qualitative research. Chicago: Aldine Publishing Company.

Hancock, J. (2011). Jen Hancock's handy humanism handbook. USA: Createspace.

Hesse-Biber, S. (2015). The problems and prospects in the teaching of mixed methods research. International Journal of Social Research Methodology, 18(5), 463-477. doi:10.1080/13645579.2015.1062622 
Hollyoak, B. (2014). Netnography: A new addition to the person environment fit research methods toolbox. Proceedings of the European Conference on Research Methods for Business \& Management Studies, 477-479.

Huber, M., \& Hutchings, P. (2005). The advancement of learning: Building the teaching commons. San Francisco, CA: Jossey-Bass.

Jones, S., Torres, V., \& Arminio, J. (2014). Negotiating the complexities of qualitative research in higher education: Fundamental elements and issues (2nd ed.). New York, NY: Routledge.

Keen, M. (1996). Teaching qualitative methods: A face-to-face encounter. Teaching Sociology, 24(April), $166-176$.

Kosinets, R. (2012). Netnography: Promo/ot(ulgat)ing a new research method. Methodological Innovations Online, 7(1), 37-45.

Kuhn, T. (1962). The structure of scientific revolutions. Chicago: University of Chicago.

Mazzoni, T. (1991). Analyzing state school policy making: An arena model. Educational Evaluation Policy and Analysis, 13, 115-138.

Mcvilly, K., Stancliffe, R., Parmenter, T., \& Burton-Smith, R. (2008). Remaining open to quantitative, qualitative and mixed-method designs: An unscientific compromise, or good research practice? In L. Glidden (Ed.), International Review of Research in Mental Retardation, 35, 151-203. Burlington, MA: Elsevier, Inc.

Onwuegbuzie, A., \& Leech, N. (2005). Taking the " $Q$ " out of research: Teaching research methodology courses without the divide between quantitative and qualitative paradigms. Quality and Quantity, 39, 267-296. doi:10.1007/s11135-004-1670-0

Ponterotto, J. (2005). Qualitative research in counseling psychology: A primer on research paradigms and philosophy of science, Journal of Counseling Psychology, 52(2), 126-136.

Sawyer, R., \& Norris, J. (2012). Duoethnography: Understanding qualitative research. Oxford University Press: USA.

Schnelker, D. (2006). The students-as-bricoleur: Making sense of research paradigms. Teaching and Teacher Education, 22(1), 42-57.

Shenton, A. (2004). Strategies for ensuring trustworthiness in qualitative research projects. Education for Information, 22(2), 63-75.

Stake, R. (2005). Qualitative case studies. In N. Denzin \& Y. Lincoln (Eds.), The sage handbook of qualitative research (3rd ed.) (pp. 500-515). Thousand Oaks, CA: Sage.

Staller, K. M. (2013). Epistemological boot camp: The politics of science and what every qualitative researcher needs to know to survive in the academy. Qualitative Social Work: Research and Practice, 12(4), 395-413.

Stallings, W. (1995). Confessions of a quantitative educational researcher trying to teach qualitative research. Educational Researcher, 24(3), 31-32.

Vygotsky, L. (1962). Thought and language. Cambridge: M.I.T. Press, Massachusetts Institute of Technology.

Yin, R. (2009). Case study research: Design and methods (4th ed.). Thousand Oaks, CA: Sage.

Webb, R. B., \& Glesne, C. (1992). Teaching qualitative research. In M. D. LeCompte, W. L. Millroy, \& J. Preissle (Eds.), The handbook of qualitative research in education (pp. 771-814). San Diego: Academic Press. 


\section{Appendix A. Worldview Exercise}

\begin{tabular}{|c|c|c|c|}
\hline $\begin{array}{l}\text { Positivist/ Post } \\
\text { Positivist }\end{array}$ & Interpretivism & Critical theory & Post modernism \\
\hline $\begin{array}{l}\text { Reality is a } \\
\text { physical and } \\
\text { observable event. }\end{array}$ & $\begin{array}{l}\text { Reality is } \\
\text { constructed } \\
\text { through local } \\
\text { human interaction. }\end{array}$ & $\begin{array}{l}\text { Reality is shaped by } \\
\text { social, political, } \\
\text { economic, and other } \\
\text { values crystallized } \\
\text { over time. }\end{array}$ & $\begin{array}{l}\text { Reality is socially co- } \\
\text { created by individuals } \\
\text { through the surrounding } \\
\text { environment. }\end{array}$ \\
\hline $\begin{array}{l}\text { The aim of research } \\
\text { is to predict and } \\
\text { explain, } \\
\text { generalizing results. }\end{array}$ & $\begin{array}{l}\text { The aim of } \\
\text { research is } \\
\text { increased } \\
\text { understanding of } \\
\text { complex human } \\
\text { phenomena to alter } \\
\text { existing power } \\
\text { relations. }\end{array}$ & $\begin{array}{l}\text { The purpose of } \\
\text { research is } \\
\text { transformation, and } \\
\text { its aim to emancipate } \\
\text { so that people are } \\
\text { capable of controlling } \\
\text { their destiny. }\end{array}$ & $\begin{array}{l}\text { The aim of research is } \\
\text { democratization and } \\
\text { uncovering what is } \\
\text { intrinsically valuable in } \\
\text { human life. }\end{array}$ \\
\hline $\begin{array}{l}\text { Truth is universal } \\
\text { and verifiable; } \\
\text { findings are } \\
\text { considered true. }\end{array}$ & $\begin{array}{l}\text { Truth is an } \\
\text { agreement between } \\
\text { members of a } \\
\text { stakeholding } \\
\text { community. }\end{array}$ & $\begin{array}{l}\text { Truth is influenced by } \\
\text { history and societal } \\
\text { structures. }\end{array}$ & $\begin{array}{l}\text { Researchers cannot } \\
\text { know or create truth. }\end{array}$ \\
\hline $\begin{array}{l}\text { The researcher can } \\
\text { and should be } \\
\text { objective. }\end{array}$ & $\begin{array}{l}\text { Objectivity is } \\
\text { impossible; rather, } \\
\text { researcher serves } \\
\text { as avenue for the } \\
\text { representation of } \\
\text { multiple voices. }\end{array}$ & $\begin{array}{l}\text { The view of } \\
\text { objectivity as a goal is } \\
\text { harmful; advocacy is } \\
\text { the aim of research. }\end{array}$ & $\begin{array}{l}\text { Researchers should } \\
\text { reject objectivity \& not } \\
\text { force natural science } \\
\text { criteria onto social sci. }\end{array}$ \\
\hline $\begin{array}{l}\text { Good research is } \\
\text { value free. }\end{array}$ & $\begin{array}{l}\text { Values are a } \\
\text { means of } \\
\text { understanding. }\end{array}$ & Values are formative. & $\begin{array}{l}\text { Values are personally } \\
\text { relative and need to be } \\
\text { understood. }\end{array}$ \\
\hline $\begin{array}{l}\text { Researchers study a } \\
\text { problem. }\end{array}$ & $\begin{array}{l}\text { Researchers live a } \\
\text { question with } \\
\text { participants. }\end{array}$ & $\begin{array}{l}\text { Researcher } \\
\text { transforms with a } \\
\text { community by } \\
\text { imagining and helping } \\
\text { to create alternatives. }\end{array}$ & $\begin{array}{l}\text { Researchers serve as } \\
\text { witnesses. }\end{array}$ \\
\hline $\begin{array}{l}\text { It is through the } \\
\text { voice and } \\
\text { jurisdiction of an } \\
\text { expert that } \\
\text { knowledge is } \\
\text { gained. }\end{array}$ & $\begin{array}{l}\text { It is through } \\
\text { voices and } \\
\text { acknowledgment } \\
\text { of both } \\
\text { participants and a } \\
\text { researcher that } \\
\text { knowledge is } \\
\text { gained. }\end{array}$ & $\begin{array}{l}\text { It is through } \\
\text { theoretical } \\
\text { perspectives of } \\
\text { societal structures in } \\
\text { conjunction with the } \\
\text { people who are most } \\
\text { affected that } \\
\text { knowledge is gained. }\end{array}$ & $\begin{array}{l}\text { Knowledge is not } \\
\text { guaranteed. Space for } \\
\text { the not known allows } \\
\text { the exposure of binaries } \\
\text { as well as the } \\
\text { juxtaposition and } \\
\text { paradox of such } \\
\text { binaries. }\end{array}$ \\
\hline $\begin{array}{l}\text { Validity is data that } \\
\text { can be duplicated. }\end{array}$ & $\begin{array}{l}\text { Validity is } \\
\text { participant and } \\
\text { inquirer } \\
\text { consensus. }\end{array}$ & $\begin{array}{l}\text { Valid research is that } \\
\text { which creates action. }\end{array}$ & $\begin{array}{l}\text { The goal of dissensus is } \\
\text { preferred over } \\
\text { consensus. }\end{array}$ \\
\hline History is progress. & & & $\begin{array}{l}\text { History portrays } \\
\text { cultural shifts. }\end{array}$ \\
\hline
\end{tabular}

Worldview Exercise. Based on Table 1.3 in Jones et al. (2014, p. 13). 


\section{Appendix B. Model for Research}

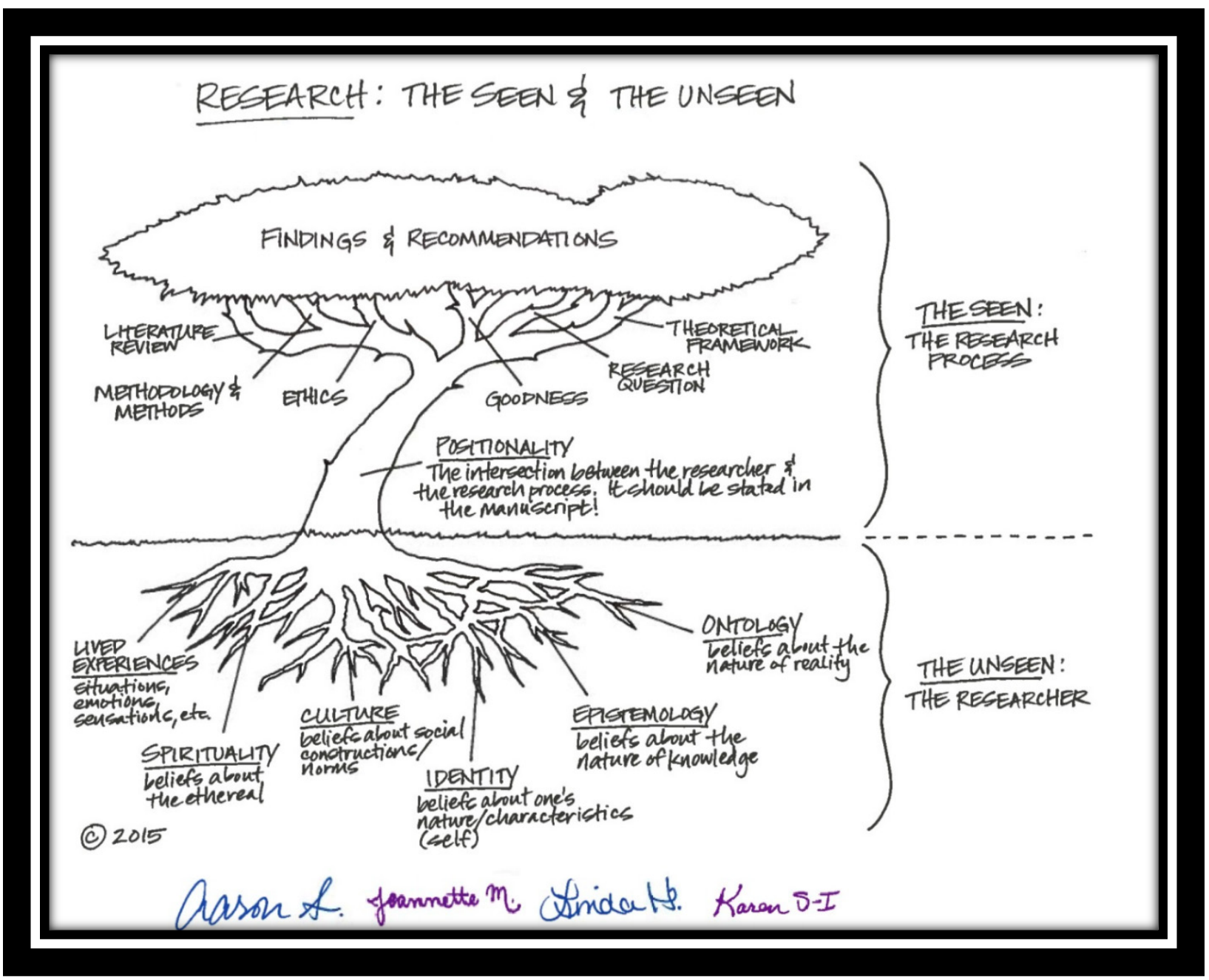

\section{Biography}

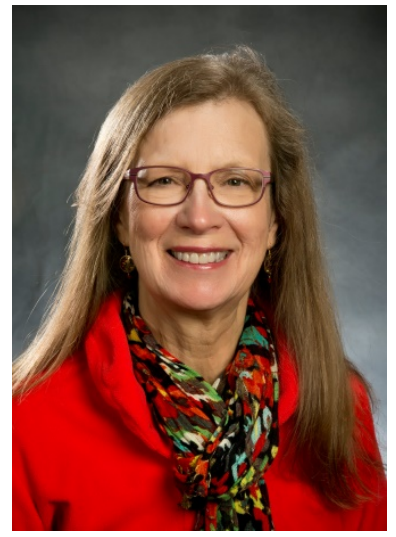

Suzanne Franco is a Professor of Research and Statistics in the College of Education and Human Services at Wright State University in Dayton, Ohio, where she is the Program Director for a new doctoral program in Organizational Studies and where she teaches Research and Statistics for numerous programs. Suzanne has also served as an evaluator and principal investigator for numerous local, state and federally funded grants, most of which deal with $\mathrm{K} 12$ and higher education STEM education as well as K12 school improvement. 